\title{
Debt in the Quebecois Novels of the 1960-1980
}

\author{
Marie-Dominique Boyce \\ Fairfield University, Fairfield CT, USA
}

\begin{abstract}
This article will study the Quebecois novels of the 1960-1980's and especially the feeling of debt that women had because of the Christian Bible that condemned women as being the sinful Eve responsable for the Fall of Humanity. These novelists from Quebec, Marie-Claire Blais, Anne Hebert, and Gabrielle Roy, show that their female characters are unable to let go of this myth of the incarnation in their bodies of the temptations leading to Sin. Consequently, these heroines show a violent disgust for their bodies, and for all sexual manifestations (puberty, pregnancey, child-birth) that they describe very crudely. They reject their bodies and live in shame of their bodies. For this reason, they dress with modesty and have a neurotic fear of the Sin of the Flesh. This Sin makes them want to withdraw from the image of the temptress Eve and to identify themselves to Mary, the sublimated woman. For Quebec novelist Gabrielle Roy, the female debt cannot be repaid by a sublimation of women to Mary, but by a sublimation of women's own talents. Gabrielle Roy sees her late birth as a debt contracted towards her very impoverished and old parents. Fortunately, in her adolescence, she rebels against this unfair contract that her family and especially her mother imposes on her and that wrongs her because it forces her to follow the career path of a school teacher to repay the debts of her family. She withdraws from this debt by leaving for France and following the career path of a writer. She will redeem the debt of her family by writing her autobiography which is a monument in sublimation of her mother.
\end{abstract}

Keywords: maternal nurturance and compassion, woman's deliverance by writing themselves, reinvention of writing “le corps feminin” by women, sensual writing

\section{Introduction}

The idea of Woman's Eternal Indebment towards Humanity because of the mythical guilt of Eve's Original Sin is a concept that the women authors of the 1960-1080’s (Marie-Claire Blais, Anne Hébert, and Gabrielle Roy) want to have abolished.

These women authors have lived their youths under the Duplessis regime, regime de "la Grande Noirceur", that maintained traditional views dominated by the Clergy in the face of young generations and a new intellectual elite that aspired to personal fulfillment. While Marie-Claire Blais and Anne Hébert fight for a re-valorisation of the female body and sexuality, Gabrielle Roy fights for a social and economic sublimation of women.

The study showed demonstrates that the feeling of debt in the Quebecois novels written by women from 1960-1980 comes from the historical and religious contexts in which they are inscribed. The historical context

Marie-Dominique Boyce, Ph.D. in French Studies/Adjunct Faculty, Modern Languages and Literatures Department, Fairfield University. 
demanded that after the defeat of the French, women become mother hens bringing forth as many children as possible to the world to counteract the invasion of the English and to show the representation of the Francophone people who remained in Canada. Women are therefore considered only for their sexuality and in relation to men's needs. The Christian morality approved of the reduction and domination of women by men as indebted woman through the original sin of creation. Around the beginning of the 1980's, we see that women are opposed to the original debt, and reclaim justice and equality in love in the novels by Anne Hebert.

The second part of the article will deal with the evolution of the debt of women which is seen in the autobiography of Roy (1988) Enchantment and Sorrow, no longer on a physical and moral level but on a social level. It is Roy's inability to pull herself away from the path of defeat of her Francophone family in Manitoba and from their request that she maintain the oral French language alive, which prevents Roy from progressing and which binds her to the poverty debt of her family. When she realizes the falsity of this family contract and when she goes away to France and England, she redeems herself from that debt and will assert herself not so much as a French teacher but as a writer of the French language.

Here is the historical context of women's debt. In 1756, French soldiers loose the battle against the English. This is the invasion of the English in French Canada. The French Canadians who remain on the continent decide not to assimilate with the English and to regroup in a distinctive society directed by the Catholic priests that also remained in Canada to evangelize the Amerindians.

In order to counteract the expansion of the British, the French leaders as well as the Church enjoin women to produce as many children as possible. Such moral principles as the submission to the husband, the giving of self, altruism, Christian charity and sacrifice for the family are required from women. They are commanded to insure the preservation of the language and the faith of the French family. The woman will be wedded and a mother or a nun, there is no other future for the woman. Nuns are entrusted with caring for the sick, the orphans, the poor, and the education of girls. Wives and mothers are ordered to become mother-laying hens, like the mother in the novel A Season in the Life of Emmanuel by Blais (1970). In this novel, the mother has a family of 16 living children (and many others are not counted in this number as they died in infancy). The mother must give all of herself to the family. We see the total abnegation of this woman who gave birth to her 16 children this very morning and goes immediately after to the fields to help out her husband. The mother's total abnegation is transcribed stylistically by the point of view of the newborn (a son) who judges her mother when she gets back home. The mother is the prisoner of the gaze of her son who awaits impatiently to be fed while the husband and the rest of the family await for their bath and their dinner. This mother is seen as an object by the gaze of the newborn son and she is completely emptied of any interior thoughts, of personal feelings.

Here is his mother. He recognizes her. She does not come towards him yet. He could believe that she has abandoned him. He recognizes her sad face, her bent shoulders. She does not seem to remember that she gave birth to him this very morning. She is cold. He sees her hands clutching the pail of milk. "He is here, says grandmother Antoinette, he is hungry, he cried the whole day". His mother is silent... His mother takes him in her arms. She protects him now with her frail body, she supports his head so that he can eat and drink in peace... (He is exhausting his mother, he is taking everything in her! His mother, she does not say anything, does not answer any longer, profound calmness, deserted maybe. He is there but she forgets about him. He does not echo in her any joy or any desire. He slips in her, he rests hopelessly. (Blais, 1970, p. 14)

The mother is seen in relation to the son. In her gestures, as seen from an outsider's point of view, it is the 
mother's duty to breastfeed and provide for the well-being of her son, already described. We do not know anything of the needs and joys of the mother.

While the mother is an automaton controlled by the husband and her family, the grandmother would seem to be liberated from the constraint of the family on her. In fact, she is the one who controls with kicks of her cane all this flood of children that the mother delivers on to the world, throughout the entire day that the parents are in the fields. But, this flood of children always presses around her, stifles her with their incessant demands, waiting "with a gaping mouth, panting with impatience and hunger for the crumbs of chocolate, and all those gluey treasures that she had accumulated and that were now springing forth from underneath her skirts and her haughty corset” (Blais, 1970, p. 12). She defends herself from the siege of all these children around her by saying "Go away, go away!” but she is constantly harassed by her family with the needs which she has to provide for them.

It is also a real struggle that the grandmother has with her son-in-law once he is back from work. The grandmother had the control of the whole household during all of the day. Now, obedience and the power over decisions on all matters concerning the whole family return to the husband. The grandmother suggests that Skinny Johnny is right to educate himself by hiding under the table, and she dreams of saving him from poverty and tuberculosis by pushing him towards priesthood. She says to him: "in the convent... there are infirmaries, heated dormitories... You will be well there...” (Blais, 1970, p. 19). But the son-in-law does not let the grandmother control him. He answers back "Grandmother, I know life better than you, I know what my children will be doing later!” (Blais, 1970, p. 14).

The grandmother defies him by refusing to bring his bowl of hot water, so then the son-in-law pulls off one of the buttons of her shirt collar to remind her of her submission and of the needs of the man, and to order her to sew the button back on. "You know that this will be you (who will sew it back on)", says the man, "It is always you, grandmother!” (Blais, 1970, p. 19).

While history indebted the woman and imposed upon her this obligation to provide for her numerous families, it is the religious context of this time period, along with politics of birth, that ruined woman. For those religious, woman must not only be a slave to the orders of her husband and of her family, showing her perfect self-sacrifice, but she was Eve who had introduced sin to the world. Her body was bluntly seen as nothing other than flesh, than material, and thus satanic. In the novel Les fous de Bassan by Hébert (1982), it is the desires of the delicate forms of the little Atkins, Nora, of 15 years old, and Olivia, of 17 years old that the entire community has in mind. Even the reverend of the community, Nicolas Jones, confesses this:

Am I going to once again put my nose in my sin (Confessing all, against the asleep body of Irene (my wife), my ecclesiastical clothes barely arranged on a chair at the foot of the bed, I weigh in secret the light weight, the delicate forms of the little Atkins? (Hébert, 1982, p. 24)

Indeed, this novel is a confession of this desire of repressed love according to religious principles, that ends in the murder of two young girls. The novel is a compilation of intimate journals of main character that tell us their unease of living, under the religious principles to see the evil in woman, the corrupting woman Eve, the temptress of the bewitching body which has no other intentions but to drag man into her downfall. According to these religious principles, man must battle against his desires and live solely for the spirit. We see the difficulty that the reverend has in attaching himself to the spirit, to the Holy Scriptures. He as well cannot resist the two 
beautiful faces of Nora and Olivia, tense towards before him during Sunday prayer at the church, and he confesses that he is perhaps the first to have corrupted this community by mixing his own desire in the words of God.

Master of Holy Scriptures, I speak to them of the name of God. For some time, I have been selecting even more carefully the Sunday psalms and hymns, thinking of the little Atkins. Their violet and ultramarine eyes raised towards me for my damnation... I am preparing them as young fiancés, attentive to the talks of love that surround them, in the light of summer. I modulate/adjust. I articulate every sound, every syllable. I make the breath of the earth pass in the Word of God. (p. 28)

Yet, the most alienated of all characters towards this idea of evil carnal desire is Stevens, a young man of 20 years old who returns to the village of his childhood Griffin Creek, after having left it five years before due to a violent brawl with this father regarding the subject of the kiss that he had given to his cousin Olivia. The father and the son throw themselves into a fury one against the other, the father wanting to eradicate his son's desire for the body, the son defending himself against the father. This ill treatment of his father and of the Puritan religion in which Stevens was raised, makes him consider women as the other.

As De Beauvoir (1949) tells it in The Second Sex:

Woman does not cease being the other, we do not consider that reciprocally male and female are both flesh; The flesh that is, to the Christian, the other enemy does not distinguish itself from the woman. (De Beauvoir, 1949, pp. 231-233)

For Stevens, woman is the enemy that he must combat and exterminate. Still humiliated by the chastisement of his father, he returns to his country to reject the responsibility of this desire for women. He intends to lay bare their desire and punish them in turn. His first victim is his cousin Maureen, a widow aged 50 years old, who falls because of her flesh when she sees her cousin naked in her bath. Stevens remarks the change in his cousin's body seduced by him, "She did not have any more strength in her arms and her legs. She began to tremble... " (Hébert, 1982, p. 19). As woman is nothing but flesh for Stevens, a sexual object, a good to be consumed for his profit, he takes her without consideration, "Everything nude is dripping wet, I take her in her room on her defeated bed. She protests and says that she could not... that she is too old... I immediately made myself at home” (Hébert, 1982, pp. 68-69).

He boasts crudely of this sexual act to his friend Mic, to whom he writes and announces:

I want her less and less, to the extent that she awakens under me, like a cat in heat. At night, despite her protests, I sleep in the barn. I repeat to her that there is my assigned place. And that I do not care for her long hair tickling my face and for her arms around my neck. I am aching all over. (Hébert, 1982, p. 69)

For Stevens and according to the teachings from the Bible that says that woman was created from one of the numerous bones of Adam, woman is an object fashioned in the function of man and for the profit of man. As says De Beauvoir (1949) in her essay The Second Sex:

Humanity is male and man defines woman not in her own self but in relation to him. Man thinks of himself without woman. She does not think of herself without man. And she is nothing other than what man decides, so one calls her "the sex", meaning to say by this that she appears essentially to the male as a sexual being: for him, she is sex, so she is it in the absolute. She determines and differentiates herself based on the man, and not here based on herself. She is the inessential against the essential. He is the subject, he is the absolute: she is the other. (De Beauvoir, 1949, p. 15) 
Stevens does not recognize the desire of Nora, who follows him like a fox in the forest in the chase for erotic feelings. Suddenly, he makes an about face, lets her advance towards him, she desiring, repeating his name pleading with love, and he insults her by reproaching her carnal desires:

"You should not do what you may regret” (De Beauvoir, 1949, p. 91).

At the burning desire of Nora, Stevens puts forward a cold ban, and he likes seeing his cousin melt from humiliation under his scathing refusal:

She freezes up. For an instant, one could believe her to be absent, sheltered by her impassive face, profoundly preoccupied inwardly at receiving the insult to swallow like a bitter potion. Little by little, her eyes become shinny, tears come slowly, drowning her look, slipping on the cheeks. This pleases me well enough. But there, where I wait all my enjoyment, I see her blaze in anger. In equal fury, I fancy you, my little cousin, and how I would like to take you in these deep woods. She treats me with "accursed Christ" and "bastard", she searches for another word that she does not yet know and calls me "tomboy". I do not yet try to restrain her on the trail path where she retreats liming on the stumps and dead branches. (De Beauvoir, 1949, pp. 91-92)

This vulnerability of the woman to be carnal and enchanting, this debt that she must repay to the men for having led them to the sin is death. It is he who commits the murder of Nora and Olivia, who defend their right to sexual desire, but that he does not listen and he strangles his cousins, rapes them, and throw them in the sea.

Only the mothers who know the power of seduction of their body survive in these puritanical communities, but do not draw vanity from it so much as guilt. They show modesty and hide the nudity of their bodies from the eyes of men. Felicity Brown refuses to cede to the wishes of her young son Nicolas to bathe with her and her cousins in the ocean at dawn, despite the tantrums of her young Nicolas who thinks that his mother prefers his cousins to her own son. A distinguished mother, felicity buries her flesh and her passions in her corset and presents herself to her son only as the refined mother, Marie of a stiffened, and compressed body, like that of a statue. The only time when she shows some passion to her son is the day where he tells her of his calling for God.

She embraces me for the first time. Her face salted like sea spray. A tear on her cheek. The long neck of my mother. Her collar bone. Her black corset stuck with pins where I did not dare lean my head on as a child. The warmth of her life under there which beats, beats like a captive bird. If I reach to open the cage? With which magical prayer which invention of crazy love could I deliver the heart of my mother? I dream about it as an impossible mission. (De Beauvoir, 1949, p. 25)

In this misogynous society where woman is declared inferior, imperfect only because of body and not spirit, and is viewed solely based on the function and needs of the husband, the woman is the prisoner of the man and his marital law, her jailer. This ill treatment of women by men breeds in the minds of children feelings that women are tortured in their rooms at night. Olivia who sees trances of blood in her mother's bed thinks to some ways that her father must have made her mother suffer. Her mother does not explain to her that these are her menstruations, too ashamed to speak about this infamy of the woman, divine punishment of having to spill blood every month to atone for her original fault.

In this manner, the rendering of women as inferior, as well as the disgust of the female body are transmitted from mother to daughters. But as we can see in the novel Les fous de Bassan, written in 1982, the woman rebels against this inferiority of her body. The young girls Nora and Olivia demand their rights to love, and they are supported by the other drowned dead mothers who make heard their growls from the sea and who reject the corpses of the young girls on the shore, accusing the community of its crimes. 
In Kamouraska by Hébert (1970), the woman puts an end to this misogynous society through the murder of Seigneur in a bath of blood. In Children of the Sabbath, Sister Julie ousts important persons, the doctors and priests, from their powers of authority, and throws upon them into a fate where it is them who have the mark of blood inferiority, in the form of burns and wounds.

In the autobiography of Roy (1988), Enchantment and Sorrow, the siege of consciousness of the debt that women have to repay to the community is not with respect to a physical or moral inferiority of women like in the novels of Marie-Claire Blais and Anne Hébert, but this debt caused by women towards the community is with respect to a social inferiority of the woman who delights in living under French traditions in poverty, at the margin of the Anglophone society of Manitoba and who refuse to take a job in this Anglophone society and to make herself valuable.

Gabrielle Roy does not talk about a physical inferiority of the female being, since this is not her internal weakness, but she analyzes that these internal pains have more to do with the financial troubles of her family. Indeed the mother, like a child, does not have a sense of reality and spends more than she can make at her small work as a seamstress. It is very often that she goes with her last daughter to take advantage of small earnings in the Anglophone neighboring city of Winnipeg and, like the "Milkwoman” with her pot of milk in La Fontaine's fable, thinks of everything that her meager money could buy.

She thought about a rug for the living room, a new dishwasher. Not yet having opened the small sum that she had at her disposal for today, this appearing to have to suffice to fill the desires that had been waiting for a long time. Others were growing at the very same moment. Mom was one of these poor people who dream, so as to have possession of the beautiful good more than people who have it at their residence and hardly see it. So it was in riches, all the possibilities of intact purchases still in our heads, that we were crossing the bridge. (Roy, 1988, p. 12)

She has to go to the evidence, once at the store, that she cannot buy anything or even buy incorrectly through impulse and leaves the store full of remorse from these purchases, warning Gabrielle to hide them to her father who is making himself a world of small debts. Gabrielle remarks that these outings in the neighboring city of Winnipeg are mostly an occasion for the mother to attack, to make worth it her rights to be of use to a compatriot French woman and to dream that she could remake history and prevent Manitoba from becoming totally English. Gabrielle, her daughter, calls her back to reality and remembers her remarks:

A good moment later, I became angry towards mom, and told her that she would see us ill to the end, and that, if we both laughed, we would also be laughed at. (Roy, 1988, p. 15)

The mother wants to continue to blame their poverty on the English and on their ancestral traditions of daily life to the French of Québec, their traditions of cultivating the soil and of being slaves to God by cultivating the garden of Eden that God had given to Canada, and to denigrate any other form of culture, particularly the culture of the mind through reading and writing.

The mother rejects this poverty debt on her daughter who studies. It is Gabrielle who will pay back the family debt:

To what mom, a bit stung, retorted that it was not up to me, who had all the chances to be instructed, to give a lecture to her who had just been able to finish the sixth grade in the small grade school of Saint Adolphe de Rodriguez... That would be up to me, the agile mind, the head not yet broken by constant calculations, to put me to learn English, so that we avenge all. (Roy, 1988, p. 15) 
Gabrielle who wrote this autobiography towards the end of her life, remembers these remarks from her mother and observes with bitterness the disturbance of this debt from generation to generation and the incapacity of Francophone people to liquidate this debt, so to finish living in the past in defeat and take life by the hand, even at the present hour of her autobiography (Roy, 1988):

Later, when I would come to Montreal and observe that things were hardly different in the stores to the west of the city, I would be knocked over and would feel that the bad luck of being French Canadian was irreparable (Roy, 1988, p.15).

This legacy of the debt, Gabrielle takes seriously and believes that she is also a cause of it, the appendicitis operation that she incurred having cost expensively, the mother always showering her small last daughter with all the pleasures. She disavows liquidating the debts of her family. She vows to her mother, who she sees is exhausted once she returns to consciousness from her operation, that she would "always be the first in her class at school".

Hypnotized by the gaze of her mother who for Gabrielle still holds the gift to erase all troubles, Gabrielle becomes chained to the debt. Her mother, such a large spider weaves, around her more and more threads of dependence, cocooning and paralyzing all sprit of independence in her. To hold Gabrielle beside her, the mother paints for her a frightening picture of all her other children who left to work far away and who only found disappointments in their work, ending up even farther and farther to teach in these villages of misery like Adèle or Anna, who married too young and smothered their talents. And Gabrielle, remarking her best chances beside her mother:

Now me, the last, I was apparently happy with my task, accomplishing my best and finding satisfaction there. I would relax with group activities, play tennis, take part in the parish meetings, later, I would join in the "Cercle Molière..., I would appear for Mom the only who was gifted with happiness”. (Roy, 1988, p. 136)

Still indebted even more gravely by her mother but laughing at all the fables that her mother invented, like Scheherazade, dreaming of arriving at unforeseen fortunes coming from such a great uncle or another who arrives just in time to seal off the arrears in the budget, Gabrielle begins to think of breaking her chains. She realizes that her gifts would be suffocated if she stayed in Manitoba.

The call of the old country becomes more and more pressing, torturing here almost and making her discover that her real path is not in Manitoba teaching spoken French language according to family traditions, but becoming a writer and writing French for the posterity.

How this project of leaving for Europe had grown and pushed, and why it overcame me until it took me without pity, I could hardly say... I was running after something but what! My writings until then mattered so little! Had I dared to reclaim them to announce that I intended to give myself wholly to the task of writing? No, it did not suit me, even with my own eyes. At the bottom of my conscience, however, I believed that I could distinguish a vision of myself in the future where I saw myself, not only becoming a writer, but trying hard, trying hard to reach it. (Roy, 1988, p. 182)

The same incident that had made her take charge of her family debt, will break her chains. Ready to depart for France, her mother trains one last effort to retain her daughter beside her and to hide the hip. Still adoring her mother, despite all her talk, Gabrielle realizes her imprisonment:

Day after day, I felt the bonds of the routine, of security, also of the affection tighten to better contain me (Roy, 1988, p. 198) 
She breaks her chains when she unmasks the game of her mother who refuses to have her hip plastered after her fall to maintain dependence of her daughter:

Never, never!

At her age, it would be madness to shut oneself up like this, she said defensively. She could not come out alive. It would be better to accept the disability...

And to shut myself up as well, to keep me forever by your side, I told her with brutality for all of a sudden, I understood that it was the only weapon that I possessed against her recalcitrant will.

She became totally pale. At the quivering of her look, I understood how the blow had struck. She lowered her eyes. (Roy, 1988, p. 199)

This departure for France is seen as a desertion of hers, of her sisters, of her brothers, and of the entire community:

No one around me supported me. Our little French, Catholic village did not raise us through the price of so much sacrifices, of abnegation and of rigor to let us leave... My sister Adèle, inclined to excessive gestures, accused me of betraying my own kind. Anna, more moderate, judged me crazy... It seemed that they had a grudge against my young self for undertaking what they, during their youth, did not dare accomplish, and were reproaching them now without any doubt. (Roy, 1988, p. 211)

She endorses this debt towards her own loved ones and makes the bet to pay it with interest all at once upon returning from France. She remembers at the moment of her departure abroad being consoled by this dream:

The great comforting dream of my youth... that I would have the time to do everything. First, save yourself. To whom is anyone of use, if one is drowning. Then, come and save the others. It seemed to me that time would be granted to me. (Roy, 1988, p. 243)

The second part of the autobiography of Roy, A bird falls on the doorstep, holds forth the debut of Roy in Paris. In Paris, Roy is very much a bird fallen from the familial nest, who must emancipate herself and face all the troubles of searching for a lodging, feeding herself, and finding her path... Everywhere she loses herself, commits blunders. While searching for a family who would welcome her like a lavish child, she only finds an old landlady in Paris, Mrs. Jouve, who snubs her for arriving so late without informing her. At her Parisian theatre auditions, where Gabrielle expects to also be acclaimed as she had been in her theatre evenings in Manitoba, she receives only reproaches on her manners and her Manitoban accent. The finishing shot occurs when her gold medals are stolen, treasures from her competitions in French, that she had won to avenge her loved ones from their poverty and from their loss of the beloved country, Acadia. All of a sudden, she understands that it is not the memory of succeeding in the competitions that makes her cry for her medals, but more the money that she could have withdrawn from them as they were in gold. It is not about her stolen clothes that she is crying about, but about the sad memories of extravagant spending that her mother reproached her for. Suddenly, all becomes clear in her mind, and she sees the pretense of the familial attachment. She understands that all the tirades of her mother were only a dramatic effect for maintaining her close to her and for enchaining her to the family's debt. She obtains the confirmation of the falseness of this ancestral way of wanting to maintain, at the price of poverty, the oral French language at Manitoba when she goes to listen to Cyrano of Bergerac at the French Comedy. All at once, she realizes that the oral tradition of French is no longer the homeland, the family that she desires. Here is what she says: 
But the sight of Cyrano, wounded to death and hours later still standing and discussing... left me at a great unease. If this were theatre, I would never believe it. It was too false. Too big! Or rather I was not meant for it. The evidence imposed itself on me little by little. It was admitting it that was difficult. For if I were in Paris, it was, as I had tried to make myself believe, to study theatre arts. (Roy, 1988, p. 274)

Rejecting the oral tradition of French of her homeland and of her family, Roy, bilingual, leaves for England. In London, she still participates in courses of theatre arts. It is in her recitation of Portia's speech in Shakespeare's The Merchant of Venice that she realizes that she can exhale her pain through the words of the English playwright, and while interpreting the role of Portia disguised as a lawyer demanding the clemency of her friend's debt to the Venetian doge, she begins to see that there is a redeeming equivalence as Cecili Francis says that circulates "between fault, esthetic gesture, and forgiveness". This is what Roy feels while reciting this speech of Portia:

Then everything started to blend and became blurred. I was no longer someone who was reading, another who was watching. I had escaped the others and myself. The shyness and the distress had blown me back far in my life. I had returned to my childhood. I was still in class at the Academy Saint Joseph. The inspector was watching our every move. Sister Agatha had pleaded me, "Stand up and save the class". And I was doing my best in the middle of the class, "Was it at the Guidhall? Was it in Saint Boniface? What was still to save, God only knew!... Had I not rejoined my old misery from the Rue Deschambault, which astonishingly seemed to exhale itself through the words of Shakespeare”. (Roy, 1988, pp. 322-323)

It is at Century Cottage, that she finds the perfect fairy tale family that welcomes her like one welcomes a prodigal child. She is exhausted, and falls like a bird on the doorstep of this little English cottage occupied by the perfects. There, she finds a family completely disinterested in the money that coddles her, and encourages her in her intellectual pursuits. Soon she comes to pass the obstacle of the white page stemming from ancestral education of the falseness and devilish forces attached to the book.

Suddenly, Roy comes to pay no heed to the ancestral veto against reading and writing books.

She starts writing and pouring out her sensitivity in her writings. Little by little, her identity is reborn through writing. She becomes more confident in herself and forgives her family for all the wrongs that they did to her. She especially forgives her mother and erects this monument, her autobiography, to immortalize her.

\section{Conclusion}

Since the history of Creation, woman was seen in comparison to man. The historical conditions of Québec menacing the French community into assimilation with the Anglophone majority reinforced this indebtedness of woman. Woman then becomes the only means to perpetuate the French race through her multiple childbirths. But in particular, it is the religious context that ruined the woman. Woman is seen as the object of man's sin, the enemy against which he must fight to save his soul. Hébert (1982) insists on this injustice in her novel Les fous de Bassan which shows woman as degraded into flesh and her sexual drives, which are all that man sees in her, a bewitching Eve, indebted from the fall of humanity. Even more gravely, Hébert shows the misogyny that is transmitted by the woman herself who is ashamed of her body and her menstruation. Hébert (1970) predicts in her novel Kamouraska the end of this absurd misogyny through the death of Lord of Kamouraska in his blood bath. For Roy, the inferiority of woman does not come from her body but from her social inferiority that, like in her mother's case, takes pleasure in living like a carefree and dreaming child begging her subsistence from the majority Anglophone society of Manitoba. 
Roy sees the difficult of Quebecers to liquidate the debt of their past, their dream destroyed by their defeat in the annexation of Canada from France. She sees the absurdity that this debt operates on her mother, always leading her to spend more. She breaks with this charge and emigrates to France and to England where she remakes her identity by becoming a writer.

\section{References}

Blais, M. C. (1970). A season in the life of Emmanuel. Montréal: Editions du Jour.

De Beauvoir, S. (1949). The second sex. Paris: Gallimard.

Hébert, A. (1970). Kamouraska. Paris: Editions du Seuil.

Hébert, A. (1975). The children of the Sabbath. Paris: Editions du Seuil.

Hébert, A. (1982). Les fous de Bassan (The shadow of the wind). Paris: Editions du Seuil.

Irigaray, L. (1974). Speculum de l'autre femme (Speculum of the other woman). Paris: Editions de Minuit.

Lacelle, E. (1979). La femme et la religion au Canada-français (Woman and religion in French Canada). Montréal: Editions Bellarmin,.

Millett, K. (1971). La politique du Mâle (Male politics). Paris: Stock.

Roy, G. (1988). Enchantment and sorrow. Montréal: Editions Boréal.

Shakespeare, W. (1964). The merchant of Venice. Paris: Garnier. 